\section{Updates on the Molecular Genetics of Colorectal Cancer}

\section{Abstract}

Colorectal cancer (CRC) is a leading cause of cancer mortality worldwide. Although definitive therapies for advanced disease are still lacking, rapid progress has been made in the last decade in understanding the molecular mechanisms underlying CRC tumorigenesis and progression. In this review, we summarize the most recent findings in the molecular genetics of CRC with a focus on gene mutations and epigenetic changes that were identified in CRC patients.

Keywords: Colorectal cancer; Molecular genetics; Gene mutations; CRC

Received: February 10, 2017; Accepted: February 15, 2017; Published: February 21, 2017

\section{Introduction}

Colorectal cancer $(C R C)$ is one of the most prevalent malignancies in the USA. With an estimated incidence of 134,490 new cases and 49,190 deaths in 2016, it is the third most common cause of cancer as well as cancer mortality in both men and women, with a five-year survival rate of less than $15 \%[1,2]$. It is a complex and multifactorial disease resulting from lifestyle, dietary, and genetic changes [3]. The majority of cases, about $75 \%$, are sporadic [1], meaning that a specific etiology has not been identified. The other $25 \%$ of cases are familial, either due to somatic changes, or hereditary genetic mutations that accounts for $5 \%$ to $6 \%$ of all CRC cases [1].

Genetic mutations in oncogenes, tumor suppressor genes, and mismatch repair genes lead to the formation of malignant cells [4-6]. Chromosomal instability (CIN) and microsatellite instability (MSI) are two molecular pathways that have been described in the progression to colorectal cancer $[7,8] .65-70 \%$ of sporadic cancers arise from the CIN pathway, which is defined by insertion, deletion, or rearrangement of entire chromosomal regions [7]. Cancers that form via the CIN pathway often have mutations in APC or KRAS [7]. MSI is characterized by a genetic or epigenetic defect in DNA repair, leading to loss of function of the MMR protein and mismatch mutations $[9,10]$. It accounts for $15 \%$ of CRC cases ( $12 \%$ sporadic, $3 \%$ due to Lynch syndrome) and it is also a part of the serrated pathway [11].

The serrated neoplasia pathway is characterized by serratedappearing precursor lesions, which are divided into hyperplastic polyps, sessile serrated adenomas, and traditional serrated adenomas. This pathway consists of gene methylation (CpG

\section{Katherine Wong and Guofeng Xie}

\author{
Division of Gastroenterology and \\ Hepatology, Department of Medicine, \\ University of Maryland School of Medicine, \\ Baltimore, USA
}

\section{Corresponding author: Guofeng Xie}

gxie@medicine.umaryland.edu

Division of Gastroenterology and Hepatology, Department of Medicine, University of Maryland School of Medicine, Baltimore, USA.

\section{Tel: 14107065962}

Citation: Katherine W, Xie G. Updates on the Molecular Genetics of Colorectal Cancer. Colorec Cancer 2017, 3:1.

island methylation phenotype, CIMP), BRAF mutations, and microsatellite instability (MSI) [12]. It accounts for $20-30 \%$ of CRC cases [13].

This article provides most recent updates in the molecular genetics of colorectal cancer. The following genetic changes have been identified in CRC patients. Table 1 summarizes the findings.

\section{MCM9 mutation}

Minichromosome maintenance (MCM) proteins play a role in initiating DNA replication [14]. MCM9 encodes DNA helicase which facilitates cellular mismatch repair [14]. Additionally, the MCM8-MCM9 complex is crucial in maintenance of the replication fork as well as double strand break repair. A genome mapping study was done by Goldberg et al. [14] in two consanguineous Ashkenazi sisters who developed mixed polyposis and metastatic CRC at an early age. Results revealed that a homozygous c.672_673delGGinsC mutation in MCM9 (chr6:119243200) was present in both sisters, while other healthy family members were heterozygous. This mutation caused a frame shift leading to premature truncation associated with polyposis and early-onset CRC [14].

\section{POT1, POLE2 and MRE11 mutations}

In a recent study by Chubb et al. [15] whole-exome sequencing was performed on 1,006 patients with early-onset familial 
Table 1 List of genetic changes in CRC patients.

\begin{tabular}{|c|c|c|c|c|}
\hline $\begin{array}{l}\text { Study/Author (Month/ } \\
\text { year of publication) }\end{array}$ & Gene & Function & Regulation/role in Colon Cancer & Type of Study \\
\hline Goldberg (12/2015) [1] & MCM9 & $\begin{array}{c}\text { Encodes DNA helicase, plays } \\
\text { an essential role in homologous } \\
\text { recombination-mediated double-strand } \\
\text { break repair. }\end{array}$ & $\begin{array}{c}\text { Homozygous c.672_673delGGinsC mutation in } \\
\text { MCM9 (chr6:119243200) caused a frame shift } \\
\text { leading to premature truncation associated with } \\
\text { polyposis and early-onset CRC }\end{array}$ & $\begin{array}{c}\text { Genome mapping study in two } \\
\text { consanguineous Ashkenazi } \\
\text { sisters }\end{array}$ \\
\hline \multirow{3}{*}{ Chubb (6/2016) [2] } & POT1 & Telomere length maintenance & Disruptive mutation & \multirow{3}{*}{$\begin{array}{l}\text { Whole-exome sequencing was } \\
\text { performed on } 1,006 \text { patients } \\
\text { with early-onset familial CRC (< } \\
55 \text { years) who also had a first- } \\
\text { degree relative with CRC }\end{array}$} \\
\hline & POLE2 & $\begin{array}{l}\text { Subunit of polymerase epsilon enzyme } \\
\text { complex }\end{array}$ & $\begin{array}{l}\text { Mutation causes polymerase proofreading- } \\
\text { associated polyposis }\end{array}$ & \\
\hline & MRE11 & $\begin{array}{l}\text { Double-strand break repair nuclease } \\
\text { involved in homologous recombination }\end{array}$ & Inactivated in mismatch repair-deficient cancer & \\
\hline Jiang $(2 / 2016)[3]$ & AFT3 & $\begin{array}{l}\text { Member of ATF/CREB family of basic } \\
\text { region leucine zipper (bZip) proteins, } \\
\text { regulates transcription by binding DNA }\end{array}$ & $\begin{array}{l}\text { ATF3 was overexpressed in human colorectal } \\
\text { cancer cells }\end{array}$ & $\begin{array}{l}\text { Investigated effects of ATF3 } \\
\text { on apoptosis, cell cycle, } \\
\text { cell migration and epithelial } \\
\text { mesenchymal transition (EMT) }\end{array}$ \\
\hline Huang $(1 / 2016)[4]$ & TET2 & $\begin{array}{l}\text { TET consists of a family of } \\
\text { enzymes that catalyze the oxidation } \\
\text { of } 5 \text {-methylcytosine }(5 \mathrm{mC}) \text { to } \\
\text { 5-hydroxymethylcytosine ( } 5 \mathrm{hmC})\end{array}$ & $\begin{array}{l}\text { Nuclear expression of TET2 is absent in a } \\
\text { significant portion of CRC tissues, in association } \\
\text { w/ metastasis }\end{array}$ & $\begin{array}{l}\text { Analyzed both the mRNA and } \\
\text { protein level of the TET family } \\
\text { members in our colorectal cancer } \\
\text { specimens }\end{array}$ \\
\hline Jia $(3 / 2016)[5]$ & $\begin{array}{l}\text { CIMP (CpG } \\
\text { island methylator } \\
\text { phenotype) }\end{array}$ & $\begin{array}{l}\text { CpG island methylator phenotype } \\
(\mathrm{CIMP}) \text { is due to hypermethylation of } \\
\text { multiple CpG islands that encompass the } \\
\text { promoter regions of multiple genes. This } \\
\text { may prevent the binding of transcription } \\
\text { factors to tumor-suppressor genes. } \\
\text { Consequently, the suppressor genes are } \\
\text { silenced which lead to the progression } \\
\text { of CRC. }\end{array}$ & $\begin{array}{l}\text { Poorer prognosis for pts w/ CIMP+/CIMP-H CRC } \\
\text { than with CIMP-/CIMP-L CRC }\end{array}$ & Systematic review of 36 studies \\
\hline Wang $(12 / 2015)[6]$ & $\begin{array}{c}\text { NAT2 } \\
\text { (N-acetyltransferase } \\
\text { 2) }\end{array}$ & $\begin{array}{l}\text { Bioactivate heterocyclic aromatic amines } \\
\text { formed in cooked meat }\end{array}$ & $\begin{array}{l}\text { Association of processed meat w/ CRC was } \\
\text { strongest among individuals with the rapid } \\
\text { NAT2 phenotype, intermediate among those w/ } \\
\text { intermediate NAT2 phenotype, and null among } \\
\text { those w/slow phenotype. Similar interaction was } \\
\text { found for NAT2 and total red meat. }\end{array}$ & $\begin{array}{l}\text { Meta-analysis; Studied in } \\
\text { Japanese and African Americans }\end{array}$ \\
\hline Olsen $(2 / 2016)[7]$ & $\begin{array}{c}\text { Caudal-related } \\
\text { homeobox } \\
\text { transcription factor } 2 \\
\text { (CDX2) }\end{array}$ & $\begin{array}{l}\text { Gene located in intestinal epithelial } \\
\text { cells that that plays an important } \\
\text { role in intestinal development and } \\
\text { differentiation by encoding intestine- } \\
\text { specific transcription factors }\end{array}$ & $\begin{array}{c}\text { Down-regulation is associated with MMR } \\
\text { deficiency, right-sided tumors, and poor } \\
\text { differentiation at both the mRNA and protein } \\
\text { level }\end{array}$ & $\begin{array}{l}\text { Evaluation of } 191 \text { tumor biopsies } \\
\text { from colon cancer patients to } \\
\text { investigate CDX2 expression in } \\
\text { colon cancer }\end{array}$ \\
\hline Liu $(12 / 2015)[8]$ & $\begin{array}{l}\text { THO complex } 1 \\
\text { (Thoc1) }\end{array}$ & $\begin{array}{l}\text { Gene that encodes nuclear matrix } \\
\text { protein playing vital roles in transcription } \\
\text { elongation and mRNA export }\end{array}$ & $\begin{array}{c}\text { Thoc } 1 \text { is involved in the development and } \\
\text { progression of CRC, and elevated expression of } \\
\text { Thoc1 is associated with aggressive phenotype } \\
\text { and poor prognosis in CRC }\end{array}$ & $\begin{array}{l}\text { Evaluation of } 185 \text { CRC samples } \\
\text { for Thoc } 1 \text { activity }\end{array}$ \\
\hline \multirow[b]{2}{*}{ Tian (10/2015) [9] } & MMP-11 & $\begin{array}{l}\text { Enzyme that catalyzes the degradation } \\
\text { of } 1 \text {-antitrypsin and insulin-like growth } \\
\text { factor binding protein-1 (IGF-BP-1) }\end{array}$ & \multirow{2}{*}{$\begin{array}{l}\text { Both CD147 and MMP-11 were over-expressed } \\
\text { on both the mRNA and protein level in CRC } \\
\text { tissue samples. They also found a direct } \\
\text { correlation between CD147 and MMP-11 } \\
\text { protein expression in CRC tissues. CD147 and } \\
\text { MMP-11 expression also influenced lymph } \\
\text { node metastasis, distant metastasis, and TNM } \\
\text { stage. Increased expression of both genes also } \\
\text { correlated with a shorter survival time. }\end{array}$} & \multirow[b]{2}{*}{$\begin{array}{l}\text { Evaluated the expression of } \\
\text { CD147 and MMP-11 in } 56 \text { tissue } \\
\text { biopsies with known CRC }\end{array}$} \\
\hline & CD147 & $\begin{array}{l}\text { Stimulates the secretion of MMPs from } \\
\text { tumor cells, as well as regulates their } \\
\text { expression and activity }\end{array}$ & & \\
\hline Wang (10/2015) [10] & $\mathrm{miR}-320 \mathrm{~b}$ & $\begin{array}{l}\text { MicroRNAs (miRNAs) are small } \\
\text { noncoding RNAs that potentially } \\
\text { play a critical role in tumorigenesis. } \\
\text { Mounting evidence indicates that one } \\
\text { specific miRNA: miR-320b is down } \\
\text { regulated in numerous human cancers, } \\
\text { including colorectal cancer (CRC) }\end{array}$ & $\begin{array}{l}\text { miR-320b expression was down regulated in } \\
\text { both CRC tissues and cells. Overexpression } \\
\text { of miR-320b in CRC cells was statistically } \\
\text { correlated with a decrease of cell growth in vitro } \\
\text { and in vivo, while c-MYC was identified as a } \\
\text { target gene of miR-320b in CRC. Furthermore, } \\
\text { it was found that up-regulation of c-Myc can } \\
\text { attenuate the effects induced by miR-320b }\end{array}$ & $\begin{array}{l}\text { Evaluated miR-320b activity in } \\
\text { CRC tissues of } 48 \text { patients }\end{array}$ \\
\hline Sun (2015) [11] & miR-206 & $\begin{array}{l}\text { microRNAs (miRNAs) are small non- } \\
\text { coding RNAs that play important role in } \\
\text { a variety of biological processes, and } \\
\text { aberrant expression of miRNA is always } \\
\text { associated with tumor progression and } \\
\text { invasion. }\end{array}$ & $\begin{array}{l}\text { miRNA-206 levels are significantly lower in CRC } \\
\text { tissue compared to control tissue. } \\
\text { patients with low miR-206 expression had } \\
\text { significantly poorer overall survival. } \\
\text { over-expression of miR-206 can inhibit CRC cell } \\
\text { migration and invasion. miR-206 functions as a } \\
\text { tumor suppressor by inhibiting CRC migration } \\
\text { and invasion. }\end{array}$ & $\begin{array}{l}\text { Evaluated miR-206 activity in } \\
\text { CRC tissues and compared it to } \\
\text { adjacent healthy tissues in } 80 \\
\text { patient }\end{array}$ \\
\hline
\end{tabular}




\begin{tabular}{|c|c|c|c|c|}
\hline Kalmar (10/2015) [12] & $\begin{array}{l}\text { MAL, PRIMA1, } \\
\text { PTGDR, SFRP1 }\end{array}$ & & $\begin{array}{l}\text { DNA hypermethylation and decreased mRNA } \\
\text { expression in colorectal adenoma and cancer }\end{array}$ & $\begin{array}{l}\text { Whole genome expression } \\
\text { profiling to evaluate the role } \\
\text { of epigenetic processes on } \\
\text { the progression of CRC. They } \\
\text { evaluated } 49 \text { colorectal adenoma } \\
\text { and } 49 \text { CRC samples and } \\
\text { compared their gene expression } \\
\text { to } 49 \text { healthy samples. }\end{array}$ \\
\hline Renaud (3/2016) [13] & MUC5AC & $\begin{array}{l}\text { Gastric mucin gene linked to the } \\
\text { serrated pathway in CRC formation }\end{array}$ & $\begin{array}{l}\text { MUC5AC hypomethylation occurs early in } \\
\text { the serrated pathway, and it is specific for } \\
\text { serrated polyps with MSI, CIMP-H, or the BRAF } \\
\text { mutation. These findings indicate that MUC5AC } \\
\text { hypomethylation may be a marker specific for } \\
\text { malignant precursors of the serrated pathway. }\end{array}$ & $\begin{array}{l}\text { Examined } M U C 5 A C \text { activity in } \\
218 \text { serrated colorectal polyps, } \\
\text { including } 42 \text { goblet cell-rich } \\
\text { hyperplastic polyps (GCHP), } \\
68 \text { microvesicular hyperplastic } \\
\text { polyps (MVHP), } 100 \text { sessile } \\
\text { serrated adenomas (SSA), } \\
\text { and eight traditional serrated } \\
\text { adenomas (TSA) }\end{array}$ \\
\hline Dai (1/2016) [14] & TCF21 & $\begin{array}{l}\text { Plays an important role in organ } \\
\text { development by promoting the transition } \\
\text { of mesenchymal to epithelial cells (MET) }\end{array}$ & $\begin{array}{l}\text { TCF21 was down-regulated via promoter } \\
\text { hypermethylation in CRC tissues. There was } \\
\text { also a direct correlation between TCF21 } \\
\text { methylation and lymph node invasion. }\end{array}$ & $\begin{array}{l}\text { Compared the expression } \\
\text { of TCF21 in } 151 \text { CRC tissue } \\
\text { samples to } 30 \text { normal samples }\end{array}$ \\
\hline Sozucan (9/2015) [15] & $\begin{array}{l}\text { Transient Receptor } \\
\text { Potential (TRP) } \\
\text { gene family: TRPV3, } \\
\text { TRPV4, TRPV5, } \\
\text { TRPM4 and TRPC6 }\end{array}$ & $\begin{array}{l}\text { Family of ion channels that consist of } \\
\text { multiple subsets of genes, including } \\
\text { TRPM (melastatin), TRPV (vanilloid), } \\
\text { and TPRC (canonical) }\end{array}$ & $\begin{array}{l}\text { Significant decrease in the expression of } \\
\text { TRPV3, TRPV4, TRPV5, TRPM4, and TRPC6 } \\
\text { genes in CRC tissues compared to healthy } \\
\text { tissue }\end{array}$ & $\begin{array}{l}\text { Investigated the expression of } \\
\text { TRPM, TRPV, and TRPC in CRC } \\
\text { tissue samples in } 93 \text { patients. }\end{array}$ \\
\hline Li (11/2015) [16] & ANGPTL4 & $\begin{array}{l}\text { Secretory glycoprotein that plays } \\
\text { many essential roles in tumorigenesis, } \\
\text { including migration, invasion, and } \\
\text { apoptosis }\end{array}$ & $\begin{array}{l}\text { Increased activity of ANGPTL4 in CRC tissue } \\
\text { compared to normal tissue, and an even higher } \\
\text { level correlated with liver metastasis }\end{array}$ & $\begin{array}{l}\text { Examined the molecular } \\
\text { mechanism of ANGPTL4 in } 54 \\
\text { colon cancer tissue samples }\end{array}$ \\
\hline Phipps (1/2016) & SNPs at $6 \mathrm{p} 12.1$ & \multirow{3}{*}{$\begin{array}{l}\text { Single nucleotide polymorphisms (SNPs) } \\
\text { are the most common type of genetic } \\
\text { variation, and they play an important role } \\
\text { in the development and progression of } \\
\text { many diseases including cancer }\end{array}$} & $\begin{array}{l}\text { Multiple SNPs at } 6 \text { p } 12.1 \text { (nearest the ELOVL5 } \\
\text { gene) which correlated with a poorer prognosis }\end{array}$ & $\begin{array}{l}\text { Genome-wide analysis of } 3494 \\
\text { patients with metastatic CRC } \\
\text { across six prospective cohorts }\end{array}$ \\
\hline Lemire (11/2015) [17] & $\begin{array}{l}\text { Locus 14q23.1, SNP } \\
\text { rs17094983 }\end{array}$ & & $\begin{array}{l}\text { SNP at 14q23.1 (rs17094983) correlated with an } \\
\text { increased risk of CRC }\end{array}$ & $\begin{array}{l}\text { rR-evaluation of a genome-wide } \\
\text { association study (GWAS) of } \\
16,517 \text { patients }\end{array}$ \\
\hline Yao (11/2015) [18] & $\begin{array}{l}\text { SNPs (single } \\
\text { nucleotide } \\
\text { polymorphisms) for } \\
\text { CASC8 gene and } \\
\text { SMAD7 gene }\end{array}$ & & $\begin{array}{c}\text { CASC8 gene: SNP of rs } 7837328 \text { and rs } 6983267 \\
\text { are risk factors for CRC among both Caucasian } \\
\text { and Asian whereas rs } 7014346 \text { and rs } 10505477 \\
\text { are risk factors only in Caucasian. } \\
\text { SMAD7 gene: rs } 4939827 \text { and rs } 4464148 \text { are } \\
\text { risk factors for CRC among Caucasian whereas } \\
\text { rs } 12953717 \text { is a risk factor in both Caucasians } \\
\text { and Asians }\end{array}$ & $\begin{array}{l}\text { Meta-analysis of } 34 \text { articles which } \\
\text { included } 90 \text { studies to evaluate } \\
\text { the correlation between SNPs of } \\
\text { the CASC8 and SMAD7 genes } \\
\text { and CRC }\end{array}$ \\
\hline
\end{tabular}

CRC ( $\leq 55$ years) who also had a first-degree relative with CRC [15]. $16 \%$ of these patients were noted to have rare germline mutations in known CRC genes compared to healthy controls. However, POT1, POLE2, and MRE11 were newly identified in this study. POT1 works in maintaining telomere length, and three disruptive mutations were noted in the CRC group [15]. POLE2 is a component of the polymerase epsilon enzyme complex. A mutation in POLE2 leads to polymerase proofreading-associated polyposis [15]. MRE11 is a nuclease involved in double strand break repair and it is active in mismatch repair-deficient cancer [15]. The findings in this study support DNA replication and repair defects as a basis for inherited CRC.

\section{ATF3 mutation}

Activating transcription factor 3 (AFT3), a member of ATF/CREB family of basic region leucine zipper (bZip) proteins, regulates transcription by binding DNA [16]. This gene is up-regulated in response to cellular stress such as hypoxia, anoxia, carcinogens, and DNA damage [17]. A study by Jiang et al. revealed that ATF3 is overexpressed in human colorectal cancer cells [18]. In CRC cells, ATF3 down-regulates the expression of the B-cell lymphoma-2 (Bcl-2), a gene that inhibits apoptosis [18]. On the other hand, ATF3 up-regulates the activity of Bak, a protein of the BCL-2 family that induces apoptosis [18].
ATF3 may also play a role in metastasis as increased expression in colorectal cancer cells is linked with invasion. Over-expression of ATF3 increases the expression cluster of differentiation 44 (CD44) and also decreases retinoblastoma (Rb) expression, both of which are CRC stem cell markers [18]. ATF3 also decreased the expression of epithelial mesenchymal transition (EMT)-inducing transcription factors, which are essential for cancer metastasis [18]. These findings suggest multiple roles for ATF3 in the CRC progression, likely through regulating apoptosis and invasion.

\section{TET2 mutation}

Ten-eleven translocation (TET) consists of a family of enzymes that catalyze the oxidation of 5-methylcytosine $(5 \mathrm{mC})$ to 5-hydroxymethylcytosine $(5 \mathrm{hmC})$ [19]. TET1 suppresses tumor progression by inhibiting the WNT pathway [20]. In CRC, a decrease in TET1 messenger RNA (mRNA) has previously been observed, leading to decreased or absent levels of $5 \mathrm{hmC}$ [19]. However, a recent study by Huang et al. also revealed a loss of nuclear expression of TET2 in CRC cells [19]. In fact, loss of TET2 was linked to a more aggressive phenotype with metastasis [19]. The role of TET2 in CRC is unclear, but it has been proposed as a tumor suppressor through post-translational modification [19]. TET2 regulates gene expression by binding with DNA in the nucleus [20]. Thus, TET1 and TET2 suppress the progression of CRC through separate mechanisms. 


\section{CpG island methylator phenotype (CIMP)}

CpG island methylator phenotype (CIMP) is due to hypermethylation of multiple CpG islands that encompass the promoter regions of multiple genes [21]. This may prevent binding of transcription factors to tumor-suppressor genes [22]. Consequently, the suppressor genes are silenced which lead to the progression of CRC [23]. A systematic review of thirty-six studies by Jia et al. revealed a poorer prognosis in CRC patients with high (CIMP-H) or positive CIMP than those with low (CIMP-L) or negative CIMP [24].

\section{$\mathrm{N}$-acetyltransferase 2 (NAT2) genotype}

Prior studies have established a correlation between red and processed meat consumption and CRC, possibly due to exposure to heterocyclic amines (HAAs) [25-27]. HAAs are chemicals that are produced when meats are cooked at high temperatures [27]. $\mathrm{N}$-acetyltransferase2 (NAT2) is a gene that activates HAAs via $\mathrm{O}$-acetylation, which forms a reactive $\mathrm{N}$-acetoxy species that binds DNA [28]. There are multiple genetic polymorphisms of NAT2 that affect its ability to catalyze HAAs. Populations with a higher frequency of the rapid NAT2 phenotype (Native Alaskans and Japanese Americans) have been noted to have a higher incidence of CRC. Contrastingly, populations with a lower frequency of this phenotype (North Africans) have a lower incidence of CRC [29].

A meta-analysis by Wang et al. examined the correlation between CRC and frequency of rapid NAT2 phenotype in Japanese and African Americans [29]. The Japanese American population had a high frequency of rapid NAT2 phenotype, whereas the African American population had an intermediate frequency. In both populations, there was a direct correlation between NAT2 activity and processed and red meat intake. There was also a stronger correlation between the rapid NAT2 phenotype and CRC than the intermediate phenotype. The slow phenotype had no correlation with CRC [29].

\section{CDX2 gene}

Caudal-related homeobox transcription factor 2 (CDX2) is a gene located in intestinal epithelial cells that that plays an important role in intestinal development and differentiation by regulating intestine-specific transcription factors [30,31]. A study by Olsen et al. evaluated 191 tumor biopsies from colon cancer patients to investigate CDX2 expression in colon cancer [31]. They discovered that CDX2 mRNA was downregulated in tumors with mismatch repair (MMR) deficiency, right-sided tumors, and poorly-differentiated tumors [31].

\section{Thoc1 gene}

The THO complex 1 (Thoc1) is a gene that encodes a nuclear matrix protein which binds the retinoblastoma protein and facilitates transcription elongation and mRNA export [32-34]. A study by Liu et al. evaluated Thoc1 activity in 185 CRC samples [35]. They discovered that Thoc 1 mRNA and protein expression was significantly higher in CRC tissue than adjacent samples of normal colonic tissue [35]. A higher level of Thoc1 was associated with a more aggressive phenotype, thus leading to decreased survival. Their results suggest that Thoc 1 may be used as a prognostic marker for CRC.

\section{CD147 and MMP-11}

Matrix metalloproteinases (MMPs) are group of enzymes that play an essential role in tumor invasion and metastasis via degradation of the extracellular matrix (ECM) during tissue growth and turnover. MMP expression is usually down-regulated in healthy tissue, but levels are increased in pathological states including inflammation and tumorigenesis [36].

Unlike other MMPs, MMP-11 (also called stromelysin-3) does not play a direct role in ECM remodeling. It catalyzes the degradation of 1-antitrypsin and insulin-like growth factor binding protein-1 (IGF-BP-1) $[37,38]$. CD147 plays a role in tissue remodeling via stimulation of extracellular matrix metalloproteinase inducer (EMMPRIN). It stimulates the secretion of MMPs from tumor cells, as well as regulates their expression and activity. Increased CD147 activity is linked to tumor growth and metastasis. CD147 has been linked to MMP-9 and MMP-2, but its correlation with MMP-11 has been unclear [39].

A study by Tian et al. evaluated the expression of CD147 and MMP-11 in 56 tissue biopsies with known CRC [40]. Compared with normal mucosa, they found that both CD147 and MMP-11 were over-expressed on both the mRNA and protein level in CRC tissue samples [40]. They also found a direct correlation between CD147 and MMP-11 protein expression in CRC tissues. CD147 and MMP-11 expression also influenced lymph node metastasis, distant metastasis, and TNM stage. Increased expression of both genes also correlated with a shorter survival time; therefore, they independently have prognostic value in CRC.

\section{miR-320b and miR-206}

MicroRNAs (miRNAs) are a class of small noncoding RNAs that are essential in post-transcriptional regulation. They degrade mRNA and inhibit translation, which leads to decreased gene expression [41-43]. MiRNA deregulation plays an important role in tumor formation and metastasis [44].

A study by Wang et al. [19] evaluated the role of miR-320b in CRC tissues of 48 patients. They found that miR-320b activity was decreased in the CRC tissues and cells. Contrastingly, they also found a direct correlation with up-regulation of miR-320b and a decrease in CRC cell growth. They also found that up-regulation of miR-320b down-regulated the expression of c-MYC, thus identifying it as a target gene. Moreover, c-Myc overexpression diminished the effects of miR-320b [45].

Sun et al. examined the activity of miR-206 in CRC tissues and compared it to adjacent healthy tissues in 80 patients [43]. They found that miRNA-206 activity was significantly down-regulated in the CRC samples. Furthermore, there was also a correlation with low miR-206 expression and poorer survival. MiR-206 may function as a tumor suppressor as up-regulation inhibits migration and invasion of CRC cells [43]. 


\section{MAL, PRIMA1, PTGDR and SFRP1}

DNA hypermethylation is an epigenetic event that occurs at gene regulatory sites, often in tumor suppressor genes. It causes decreased or absent gene expression, leading to the development of CRC [46-48]. MiRNAs (as previously described in the Wang et al. [19] and Sun et al. [43] studies) are epigenetic regulators through the posttranscriptional and translation processes of mRNAs. Altered expression of certain miRNAs leads to CRC progression [49].

Kalmar et al. performed whole genome expression profiling to evaluate the role of epigenetic processes on the progression of CRC. They evaluated 49 colorectal adenoma and 49 CRC samples and compared their gene expression to 49 healthy samples [50]. They identified 18 genes (including MAL, SFRP1, SULT1A1, PRIMA1, and PTGDR) which were down-regulated in both the adenoma and carcinoma samples compared to healthy tissues. Three of these genes (COL1A2, SFRP2, SOCS3) exhibited hypermethylation and THBS2 showed hypomethylation. BCL2, PRIMA1 and PTGDR were also hypermethylated but only in the CRC samples. In adenoma samples, miR-21 was overexpressed [50]. Epigenetic alterations of the identified genes and miRNAs may play an important role in CRC formation.

\section{MUC5AC}

MUC2 and MUC5AC are intestinal and gastric mucin genes, respectively, that have been linked to the serrated pathway in CRC formation [12].

Renaud et al. examined MUC2 and MUC5AC activity in 218 serrated colorectal polyps, including 42 goblet cell-rich hyperplastic polyps (GCHP), 68 microvesicular hyperplastic polyps (MVHP), 100 sessile serrated adenomas (SSA), and eight traditional serrated adenomas (TSA). They demonstrated that MUC5AC hypomethylation occurs early in the serrated pathway, and it is specific for serrated polyps with MSI, CIMP-H, or the BRAF mutation. These findings indicate that MUC5AC hypomethylation may be a marker specific for malignant precursors of the serrated pathway [51].

They also demonstrated that MUC5AC hypomethylation was found only in MVHPs and SSAs, but not GCHPs. Therefore, it may also be used as a marker to distinguish GCHPs from MVHPs and SSAs. There was also a gradual increase in MUC5AC hypomethylation frequency from MVHP to SSA, indicating that MVHP may give rise to SSA and sessile serrated adenomas with dysplasia (SSA/D) [51].

\section{TCF21}

Transcription factor 21 (TCF21) plays an important role in organ development by promoting the transition of mesenchymal to epithelial cells (MET). Down-regulation of TCF21 via promoter hypermethylation has been associated with multiple cancers, including lung, kidney, and heart [52].

A study by Dai et al. compared the expression of TCF21 in 151 CRC tissue samples to 30 normal samples. They demonstrated that TCF21 was down-regulated via promoter hypermethylation in CRC tissues. There was also a direct correlation between TCF21 methylation and lymph node invasion. Furthermore, TCF21 activity was restored with demethylation of CRC cell lines, inhibiting cell growth and invasion and promoting apoptosis. These results indicate that the TCF21 gene may serve as a tumor suppressor [53].

\section{Transient Receptor Potential (TRP) gene family}

Transient Receptor Potential (TRP) is a family of ion channels that consist of multiple subsets of genes, including TRPM (melastatin), TRPV (vanilloid), and TPRC (canonical) [54]. Up-regulation of certain TRP's have previously been described in cancer cells, and it has been suggested that they are involved in multiple processes including cell proliferation, tumor invasion, cell differentiation, angiogenesis, and apoptosis [54,55]. Sozucan et al. investigated the expression of TRPM, TRPV, and TRPC in CRC tissue samples in 93 patients [56]. They discovered that there was a significant decrease in the expression of TRPV3, TRPV4, TRPV5, TRPM4, and TRPC6 genes in CRC tissues compared to healthy tissue, possibly due to epigenetic factors.

\section{ANGPLT4}

Angiopoietin-like protein 4 (ANGPTL4) is a secreted protein that plays many essential roles in tumorigenesis, including migration, invasion, and apoptosis $[57,58]$. ANGPTL4 is up-regulated in CRC tissues, and a study by Li et al. examined the molecular mechanism of this gene in 54 colon cancer tissue samples [57]. They determined that there was increased activity of ANGPTL4 in CRC tissue compared to normal tissue, and an even higher level correlated with liver metastasis. Molecular analysis revealed that over-expression of ANGPTL4 up-regulated bone morphogenetic protein 7 (BMP7). Furthermore, silencing of BMP7 expression reversed ANGPTL4 activity in HCT116 cells. They concluded that ANGPTL4 may be a promoter of CRC metastasis via up-regulation of BMP7 [57].

\section{Single nucleotide polymorphisms}

Single Nucleotide Polymorphisms (SNPs): Single nucleotide polymorphisms (SNPs) are the most common type of genetic variation [59], and they play an important role in the development and progression of many diseases including cancer.

A genome-wide analysis of 3494 patients with metastatic CRC across six prospective cohorts was done by Phipps et al. [60] They discovered multiple SNPs at $6 \mathrm{p} 12.1$ (nearest the ELOVL5 gene) which correlated with a poorer prognosis. These SNPs have been associated with a two-fold shorter survival and include the minor alleles at rs17544464, rs209489, and rs1442089 [60]. The ELOVL5 gene encodes a fatty acid elongase, and knockout of this gene in mouse models has been associated with hepatic steatosis [61], which is an independent risk factor for distant metastatic CRC [62].

Lemire et al. [63] performed a re-evaluation of a genome-wide association study (GWAS) of 16,517 patients. It revealed that an SNP at 14q23.1 (rs17094983) correlated with an increased risk of CRC. This locus is associated with the Reticulon 1 (RTN1) gene 
which regulates cancer cell proliferation and survival. This gene is up-regulated in healthy colon tissue but down-regulated in cancer cells [63].

CASC8 and SMAD7 gene polymorphisms: Cancer susceptibility candidate 8 (CASC8) gene is a noncoding RNA (IncRNA) located on $8 \mathrm{q} 24.21$ which regulates gene expression [64,65]. SMAD7 is a gene located on $18 \mathrm{q} 21$. It is a member of the transforming growth factor- $\beta$ (TGF- $\beta$ ) family, in the anti-inflammatory signaling pathway which also plays a role in the metastasis of solid tumors [66-68]. SMAD7 inhibits TAK1 by binding TAB2 and TAB3, which potentiates the effects of TGF- $\beta[66,67]$.

Yao et al. conducted a meta-analysis of 34 articles which included 90 studies to evaluate the correlation between SNPs of the CASC8 and SMAD7 genes and CRC [3]. They discovered that the rs7837328 and rs6983267 SNPs of the CASC8 gene were linked with an increased risk of CRC in both Caucasian and Asian patients. SNPs of rs7014346 and rs10505477 also correlated with an increased risk of CRC but only in Caucasians [3].

A rs12953717 SNP of the SMAD7 gene correlated with an increased risk of CRC in both Caucasians and Asians. On the other hand rs4939827 and rs4464148 SNPs correlated with an increased risk of CRC only in Caucasians [3].

\section{Future Directions}

The identification of new genes and SNPs associated with CRC in the aforementioned studies provide new insights into the pathophysiology and progression for CRC. These genes may serve as CRC prognostic markers as well as molecular targets for novel CRC therapies. Additional studies focusing on potential interactions between these genes and known CRC molecular pathways such as APC-Wnt signaling will further enhance our understanding of molecular genetics of CRC. 


\section{References}

1 Genetics of Colorectal Cancer (PDQ(R)): Health Professional Version. PDQ Cancer Information Summaries. Bethesda (MD), 2002.

2 Siegel R, Desantis C, Jemal A (2014) Colorectal cancer statistics. CA Cancer J Clin 64: 104-117.

3 Yao K, Hua L, Wei L, Meng J, Hu J (2015) Correlation Between CASC8, SMAD7 Polymorphisms and the Susceptibility to Colorectal Cancer: An Updated Meta-Analysis Based on GWAS Results. Medicine (Baltimore) 94: e1884.

4 Fearon ER, Vogelstein B (1990) A genetic model for colorectal tumorigenesis. Cell 61: 759-767.

5 Hanahan D, Weinberg RA (2000) The hallmarks of cancer. Cell 100: 57-70.

6 Hanahan D, Weinberg RA (2011) Hallmarks of cancer: the next generation. Cell 144: 646-674.

7 Al-Sohaily S, Biankin A, Leong R, Kohonen-Corish M, Warusavitarne J (2012) Molecular pathways in colorectal cancer. J Gastroenterol Hepatol 27: 1423-1431.

8 Raskov H, Pommergaard HC, Burcharth J, Rosenberg J (2014) Colorectal carcinogenesis--update and perspectives. World J Gastroenterol 20: 18151-18164.

9 Martin SA, Lord CJ, Ashworth A (2010) Therapeutic targeting of the DNA mismatch repair pathway. Clin Cancer Res 16: 5107-5113.

10 Poulogiannis G, Frayling IM, Arends MJ (2010) DNA mismatch repair deficiency in sporadic colorectal cancer and Lynch syndrome. Histopathology 56: 167-179.

11 Sinicrope FA, Sargent DJ (2012) Molecular pathways: microsatellite instability in colorectal cancer: prognostic, predictive, and therapeutic implications. Clin Cancer Res 18: 1506-1512.

12 Gibson JA, Hahn HP, Shahsafaei A, Odze RD (2011) MUC expression in hyperplastic and serrated colonic polyps: lack of specificity of MUC6. Am J Surg Pathol 35: 742-749.

13 Bettington M, Walker N, Clouston A, Brown I, Leggett B, et al. (2013) The serrated pathway to colorectal carcinoma: current concepts and challenges. Histopathology 62: 367-386.

14 Goldberg Y, Halpern N, Hubert A, Adler SN, Cohen S, et al. (2015) Mutated MCM9 is associated with predisposition to hereditary mixed polyposis and colorectal cancer in addition to primary ovarian failure. Cancer Genet 208: 621-624.

15 Chubb D, Broderick P, Dobbins SE, Frampton M, Kinnersley B, et al. (2016) Rare disruptive mutations and their contribution to the heritable risk of colorectal cancer. Nat Commun 7: 11883.

16 Hai T, Wolford CC, Chang YS (2010) ATF3, a hub of the cellular adaptiveresponse network, in the pathogenesis of diseases: is modulation of inflammation a unifying component? Gene Expr 15: 1-11.

17 Liang G, Wolfgang CD, Chen BP, Chen TH, Hai T (1996) ATF3 gene. Genomic organization, promoter, and regulation. J Biol Chem 271: 1695-1701.

18 Jiang X, Kim KJ, Ha T, Lee SH (2016) Potential Dual Role of Activating Transcription Factor 3 in Colorectal Cancer. Anticancer Res 36: 509-516.

19 Huang Y, Wang G, Liang Z, Yang Y, Cui L, et al. (2016) Loss of nuclear localization of TET2 in colorectal cancer. Clin Epigenetics 8: 9.

20 Neri F, Dettori D, Incarnato D, Krepelova A, Rapelli S, et al. (2015) TET1 is a tumour suppressor that inhibits colon cancer growth by derepressing inhibitors of the WNT pathway. Oncogene 34: 41684176.

21 Jover R, Nguyen TP, Perez-Carbonell L, Zapater P, Paya A, et al. (2011) 5-Fluorouracil adjuvant chemotherapy does not increase survival in patients with $\mathrm{CpG}$ island methylator phenotype colorectal cancer. Gastroenterology 140: 1174-1181.

22 Kim YS, Deng G (2007) Epigenetic changes (aberrant DNA methylation) in colorectal neoplasia. Gut Liver 1: 1-11.

23 Herman JG, Baylin SB (2003) Gene silencing in cancer in association with promoter hypermethylation. N Engl J Med 349: 2042-2054.

24 Jia M, Gao X, Zhang Y, Hoffmeister M, Brenner H (2016) Different definitions of $\mathrm{CpG}$ island methylator phenotype and outcomes of colorectal cancer: a systematic review. Clin Epigenetics 8: 25.

25 Alexander DD, Cushing CA (2011) Red meat and colorectal cancer: a critical summary of prospective epidemiologic studies. Obes Rev 12: e472-93.

26 Alexander DD, Miller AJ, Cushing CA, Lowe KA (2010) Processed meat and colorectal cancer: a quantitative review of prospective epidemiologic studies. Eur J Cancer Prev 19: 328-341.

27 Cross AJ, Sinha R (2004) Meat-related mutagens/carcinogens in the etiology of colorectal cancer. Environ Mol Mutagen 44: 44-55.

28 Butler MA, Lang NP, Young JF, Caporaso NE, Vineis P, et al. (1992) Determination of CYP1A2 and NAT2 phenotypes in human populations by analysis of caffeine urinary metabolites. Pharmacogenetics 2 : 116-127.

29 Wang H, Iwasaki M, Haiman CA, Kono S, Wilkens LR, et al. (2015) Interaction between Red Meat Intake and NAT2 Genotype in Increasing the Risk of Colorectal Cancer in Japanese and African Americans. PLoS One 10: e0144955.

30 Werling RW, Yaziji H, Bacchi CE, Gown AM (2003) CDX2, a highly sensitive and specific marker of adenocarcinomas of intestinal origin: an immunohistochemical survey of 476 primary and metastatic carcinomas. Am J Surg Pathol 27: 303-310.

31 Olsen J, Eiholm S, Kirkeby LT, Espersen ML, Jess P, et al. (2016) CDX2 downregulation is associated with poor differentiation and MMR deficiency in colon cancer. Exp Mol Pathol 100: 59-66.

32 Dominguez-Sanchez MS, Barroso S, Gomez-Gonzalez B, Luna R, Aguilera A (2011) Genome instability and transcription elongation impairment in human cells depleted of THO/TREX. PLoS Genet 7: e1002386.

33 Durfee T, Mancini MA, Jones D, Elledge SJ, Lee WH (1994) The amino-terminal region of the retinoblastoma gene product binds a novel nuclear matrix protein that co-localizes to centers for RNA processing. J Cell Biol 127: 609-622.

34 Luna R, Rondon AG, Aguilera A (2012) New clues to understand the role of THO and other functionally related factors in mRNP biogenesis. Biochim Biophys Acta 1819: 514-520.

35 Liu C, Yue B, Yuan C, Zhao S, Fang C, et al. (2015) Elevated expression of Thoc1 is associated with aggressive phenotype and poor prognosis in colorectal cancer. Biochem Biophys Res Commun 468: 53-58.

36 Sorsa T, Tjaderhane L, Salo T (2004) Matrix metalloproteinases (MMPs) in oral diseases. Oral Dis 10: 311-318.

37 Manes S, Mira E, Barbacid MM, Cipres A, Fernandez-Resa P, et al. (1997) Identification of insulin-like growth factor-binding protein-1 
as a potential physiological substrate for human stromelysin-3. J Bio Chem 272: 25706-25712.

38 Pei D, Majmudar G, Weiss SJ (1994) Hydrolytic inactivation of a breast carcinoma cell-derived serpin by human stromelysin-3. J Biol Chem 269: 25849-25855.

39 Kessenbrock K, Plaks V, Werb Z (2010) Matrix metalloproteinases: regulators of the tumor microenvironment. Cell 141: 52-67.

40 Tian X, Ye C, Yang Y, Guan X, Dong B, et al. (2015) Expression of CD147 and matrix metalloproteinase-11 in colorectal cancer and their relationship to clinicopathological features. J Transl Med 13: 337.

41 Bartel DP (2004) MicroRNAs: genomics, biogenesis, mechanism, and function. Cell 116: 281-297.

42 Cannell IG, Kong YW, Bushell M (2008) How do microRNAs regulate gene expression? Biochem Soc Trans 36: 1224-1231.

43 Sun P, Sun D, Wang X, Liu T, Ma Z, et al. (2015) miR-206 is an independent prognostic factor and inhibits tumor invasion and migration in colorectal cancer. Cancer Biomark 15: 391-396.

44 Wu ZS, Wang CQ, Xiang R, Liu X, Ye S, et al. (2012) Loss of miR133a expression associated with poor survival of breast cancer and restoration of miR-133a expression inhibited breast cancer cell growth and invasion. BMC Cancer 12: 51

45 Wang H, Cao F, Li X, Miao H, E J, et al. (2015) miR-320b suppresses cell proliferation by targeting c-Myc in human colorectal cancer cells. BMC Cancer 15: 748.

46 Baylin SB, Herman JG, Graff JR, Vertino PM, Issa JP (1998) Alterations in DNA methylation: a fundamental aspect of neoplasia. Adv Cancer Res 72: 141-196.

47 Kim MS, Lee J, Sidransky D (2010) DNA methylation markers in colorectal cancer. Cancer Metastasis Rev 29: 181-206.

48 Sakai T, Toguchida J, Ohtani N, Yandell DW, Rapaport JM, et al. (1991) Allele-specific hypermethylation of the retinoblastoma tumorsuppressor gene. Am J Hum Genet 48: 880-888.

49 Schetter AJ, Okayama H, Harris CC (2012) The role of microRNAs in colorectal cancer. Cancer J 18: 244-252.

50 Kalmar A, Peterfia B, Hollosi P, Galamb O, Spisak S, et al. (2015) DNA hypermethylation and decreased mRNA expression of MAL, PRIMA1, PTGDR and SFRP1 in colorectal adenoma and cancer. BMC Cancer 15: 736.

51 Renaud F, Mariette C, Vincent A, Wacrenier A, Maunoury V, et al. (2016) The serrated neoplasia pathway of colorectal tumors: Identification of MUC5AC hypomethylation as an early marker of polyps with malignant potential. Int J Cancer 138: 1472-1481.

52 Quaggin SE, Schwartz L, Cui S, Igarashi P, Deimling J, et al. (1999) The basic-helix-loop-helix protein pod1 is critically important for kidney and lung organogenesis. Development 126: 5771-5783.
53 Dai Y, Duan H, Duan C, Zhou R, He Y, et al. (2016) Down-regulation of TCF21 by hypermethylation induces cell proliferation, migration and invasion in colorectal cancer. Biochem Biophys Res Commun 469: 430-436.

54 Santoni G, Farfariello V (2011) TRP channels and cancer: new targets for diagnosis and chemotherapy. Endocr Metab Immune Disord Drug Targets 11: 54-67.

55 Prevarskaya N, Zhang L, Barritt G (2007) TRP channels in cancer. Biochim Biophys Acta 1772: 937-946.

56 Sozucan Y, Kalender ME, Sari I, Suner A, Oztuzcu S, et al. (2015) TRP genes family expression in colorectal cancer. Exp Oncol 37: 208-212.

57 Li X, Chen T, Shi Q, Li J, Cai S, et al. (2015) Angiopoietin-like 4 enhances metastasis and inhibits apoptosis via inducing bone morphogenetic protein 7 in colorectal cancer cells. Biochem Biophys Res Commun 467: $128-134$

58 Guo L, Li SY, Ji FY, Zhao YF, Zhong Y, et al. (2014) Role of Angpt/4 in vascular permeability and inflammation. Inflamm Res 63: 13-22.

59 Wang DG, Fan JB, Siao CJ, Berno A, Young P, et al. (1998) Largescale identification, mapping, and genotyping of single-nucleotide polymorphisms in the human genome. Science 280: 1077-1082.

60 Phipps Al, Passarelli MN, Chan AT, Harrison TA, Jeon J, et al. (2016) Common genetic variation and survival after colorectal cancer diagnosis: a genome-wide analysis. Carcinogenesis 37: 87-95.

61 Moon YA, Hammer RE, Horton JD (2009) Deletion of ELOVL5 leads to fatty liver through activation of SREBP-1c in mice. J Lipid Res 50 : 412-423.

62 Lin XF, Shi KQ, You J, Liu WY, Luo YW, et al. (2014) Increased risk of colorectal malignant neoplasm in patients with nonalcoholic fatty liver disease: a large study. Mol Biol Rep 41: 2989-2997.

63 Lemire M, Qu C, Loo LW, Zaidi SH, Wang H, et al. (2015) A genomewide association study for colorectal cancer identifies a risk locus in 14q23.1. Hum Genet 134: 1249-1262.

64 Guttman M, Amit I, Garber M, French C, Lin MF, et al. (2009) Chromatin signature reveals over a thousand highly conserved large non-coding RNAs in mammals. Nature 458: 223-227.

$65 \mathrm{Ma} \mathrm{G}, \mathrm{Gu}$ D, Lv C, Chu H, Xu Z, et al. (2015) Genetic variant in 8q24 is associated with prognosis for gastric cancer in a Chinese population. J Gastroenterol Hepatol 30: 689-695.

66 Blobe GC, Schiemann WP, Lodish HF (2000) Role of transforming growth factor beta in human disease. N Engl J Med 342: 1350-1358.

$67 \mathrm{Hu} \mathrm{Y,} \mathrm{Sun} \mathrm{Z,} \mathrm{Zhang} \mathrm{A,} \mathrm{Zhang} \mathrm{J} \mathrm{(2014)} \mathrm{SMAD7} \mathrm{rs12953717}$ polymorphism contributes to increased risk of colorectal cancer. Tumour Biol 35: 695-699.

68 Lamora A, Talbot J, Bougras G, Amiaud J, Leduc M, et al. (2014) Overexpression of smad7 blocks primary tumor growth and lung metastasis development in osteosarcoma. Clin Cancer Res 20: 50975112. 